\title{
KEANEKARAGAMAN MIKROALGA SEBAGAI BIOINDIKATOR PENCEMARAN DI SITU CIBANTEN KECAMATAN CIOMAS KABUPATEN SERANG BANTEN
}

(diterima 5 Januari 2021, diperbaiki 10 Februari 2021, disetujui 15 April 2021)

\section{Rt Inu Rahayu, Hadi Susilo*}

Program Studi Biologi Fakultas Sains, Farmasi, dan Kesehatan Universitas Mathla'ul Anwar Banten Indonesia

Email korespondensi*: hadisusilo1973@gmail.com

\begin{abstract}
Mikroalge has role as a bioindicator of water pollutions and has many banefits incluiding as food ingridients, medicinal drugs, and cosmetic ingridients. This study aims to determine the richness of mikroalgae species in situ Cibanten. This reaearch uses purposive sampling method. The sample is taken in the morning at 08.00-12.00 AM. Sampling by filtering with plankton net with a mesh size $50 \mu \mathrm{m}$. samples that have been taken preserved with formalin $4 \%$, sample observed under a microscope in the laboratory of Fakultas Sains Farmasi dan kesehatan Unma Banten. Microalgae that found at Situ Cibanten The highest Diversity Index is at station 1 is 3.110 and the lowest is at station 2 is 2.360. The highest evenness index is at station 1 is 0.978 while the lowest evenness index at station 2 is 0.803. The dominance index in each species found a number that was almost close to zero so that the dominance index was low. And the highest relative abundance index was found in Spirogyrasp is of $17.7 \%$ and the lowest was found in Phacuslongicaida and Lemaneaannulata species is $0.4 \%$. Situ Cibanten is moderately polluted.
\end{abstract}

Keywords: Microalgae Biodiversity; Bioindicator; Situ Cibanten.

Abstrak. Mikroalgae dapat berperan sebagai bioindikator pencemaran air dan mempunyai banyak manfaat antara lain: sebagai komponen pangan, bahan obat, dan kosmetik. Tujuan penelitian ini untuk mengetahui kelimpahan spesies miroalgae di Situ Cibanten Ciomas Kabupaten Serang. Penelitian menggunakan metode purpossive sampling, sampel diambil pada pagi hari jam 08.00-12.00. Sampel disaring menggunakan plankton net dengan ukuran mesh 50 $\mu \mathrm{m}$. Sampel kemudian ditambahkan dengan formalin $4 \%$ dan diamati dengan menggunakan mikroskop di Laboratorium Terpadu Fakultas Sains, Farmasi, dan Kesehatan Universitas Mathla'ul Anwar Banten. Indeks diversitas tertinggi didapatkan di lokasi satasiun 1 dengan nilai 3.11. dan terendah pada stasiun 2 sebesar 2.360. Indek Kemerataan tertinggi pada stasiun 1 sebesar 0.978 dan terendah pada stasiun 2 sebesar 0.803 . Indeks dominasi dari masingmasing spesies mendekati nilai 0 , yang berarti nilai dominansinya rendah. Indeks kelimpahan relatif ditemukan pada spesies Spirogyrasp is of $17.7 \%$, dan yang terendah adalah spesies Phacuslongicaida and Lemaneaannulata $0.4 \%$. Situ Cibanten mengalami pencemaran sedang.

Kata Kunci: Biodiversitas mikroalga; Bioindikator; Situ Cibanten.

(C) hak cipta dilindungi undang-undang 


\section{PENDAHULUAN}

Indonesia merupakan tempat yang kaya akan ekosistem perairan. Ekosistem air tawar memiliki nilai penting yang sangat berarti dalam kehidupan manusia.Ekosistem air tawar merupakan sumber paling praktis dan murah untuk memenuhi kepentingan domestik dan industri (Soetanto, 2012).

Danau merupakan salah satu sistem akuatik tawar yang dikelilingi oleh daratan dan terbentuk secara alami. Air yang masuk kedalam danau berasal dari air hujan, mencairnya gletser, aliran sungai, dan adanya mata air (Suwono, 2013). Istilah situ biasanya digunakan oleh masyarakat jawa barat untuk sebutan danau kecil (Puspita dkk., 2005).

Perairan situ berperan penting dalam lingkungan. Situ memiliki peran diantaranya sebagai pemasok air kedalam lapisan batuan dibawah permukaan tanah yang digunakan sebagai daerah resapan air tanah. Selain itu situ juga berperan membantu memperbaiki air permukaan melalui proses fisik kimia biologis yang berlangsung didalamnya, termasuk irigasi, rekreasi, tandon air/reservoir, mengatur iklim mikro, dan pendukung keanekaragaman hayati perairan (Puspita, dkk., 2005)

Situ Cibanten merupakan salah satu perairan tergenang yang memiliki peran penting diwilayah kabupaten Serang. Masyarakat sekitar situ memanfaatkan situ Cibanten terutama untuk kegiatan mandi dan mencuci. Aktivitas masyarakat di lingkungan situ berdampak adanya pencemaran air. Pencemaran air merupakan aktifitas makhluk hidup, zat, energi, atau komponen lain kedalam air sehingga kualitas air menjadi berkurang dan fungsinya tidak sesuai dengan peruntukannya. (Saefullah dkk., 2015).

Biodiversitas dapat digunakan untuk mendeteksi perubahan lingkungan dan menggambarkan kondisi lingkungan masih dapat terpelihara atau tercemar (Hadi dkk, 2021). Alga merupakan tumbuhan talus yang hidup diperairan laut maupun perairan tawar, habitatnya lembab atau basah. Pergerakan alga bergerak secara motil maupun non motil sesuai dengan jenisnya (Tjitrosoepomo, 2014).

Mengetahui keragaman jenis organisme mikroalga merupakan tolak ukur dalam sebuah ekosistem, baik ekosistem perairan tawar atau perairan air laut. Mikroalga termasuk dalam kelompok mikrobia karena mikroalga termasuk prostista mirip 
tumbuhan yang keberadaannya sebagai patauan terhadap kondisi dan keberlangsungan ekosistem perairan (Pelczar, 2008).

Mikroalga yang terapung di air merupakan bagian dari fitoplankton. Fitoplankton yang mendominasi pada air tawar umumnya terdiri dari divisi Bacillariophyta (diatom) dan Chlorophyta (ganggang hijau). Karena kedua divisi ini mempunyai kemampuan baik dari menyesuaikan dengan lingkungannya dan berkembang biak dengan cepat (Pambudi, dkk., 2016).

Mikroalga mempunyai tiga macam pigmen fotosintetik yaitu klorofil, karotenoid dan fikobilin. Semua pigmen fotosintetik ini terdapat pada kloroplas alga. Semua alga mempunyai klorofi-a yang terdapat disemua organisme fotosintetik. Klorofil yang lainnya adalah klorofil b, c, d, dan e yang dibedakan menurut struktur molekuler dan dapat menentukan gelombang cahaya yang bisa diserap oleh tipe klorofil sebagai energi (Pelczar, 2008).

\section{METODE}

\section{Waktu dan tempat penelitian}

Penelitian dilaksanakan pada bulan Desember 2019- Januari 2020. Pengambilan sampel penelitian ini dilakukan di Situ Cibanten kecamatan Ciomas Kab. Serang Banten (Gambar 1). Sampel yang diperoleh dilapangan diidentifikasi di Laboraturium Terpadu Fakultas Sains, Farmasi dan Kesehatan UNMA Banten.

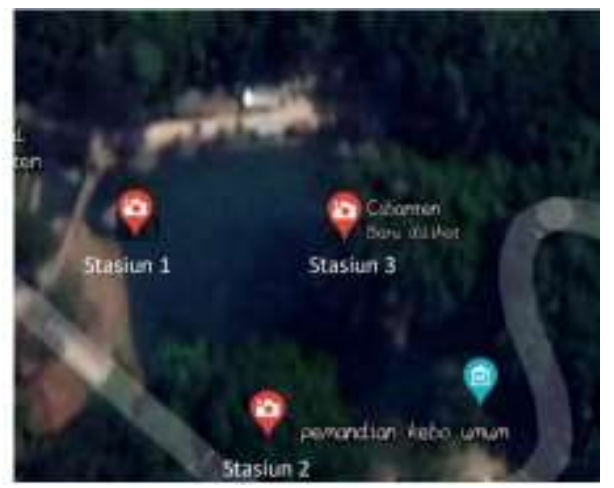

Gambar 1. Lokasi Situ Cibanten

\section{Alat Dan Bahan Penelitian}

Alat yang akan digunakan dalam penelitian ini yaitu sebagai berikut: Plankton net, ember, $\mathrm{pH}$ meter, secci disk, termometer, botol sampel, kertas label, 
mikroskop cahaya binokuler, alat tulis, tissue/ kain lap, kaca benda, kaca penutup, kamera (Hand phone Oppo A 71). Bahan yang digunakan dalam penelitian ini adalah Mikroalga, formalin $4 \%$.

\section{Prosedur Penelitian}

Prosedur penelitian untuk masingmasing stasiun antara lain Penentuan stasiun pengambilan sampel mikroalga, pengukuran faktor fisik di masing-masing stasiun di sungai meliputi suhu, kecerahan, oksigen terlarut dan keasaman (PH). Selanjutnya mengambil sampel air dan disaring dengan plankton net, sampel mikroalga selanjutnya dipindahkan ke botol sampel kemudian diberi formalin $4 \%$ 2-3 tetes, di tutup dan diberikan label, kemudian sampel di analisis dan di identifikasi (Harmoko, 2018)

\section{Analisis Data}

\section{Klasifikasi Mikroalga}

Mikroalga diidentifikasi berdasarkan buku identifikasi serta referensi jurnal relevan. Data keanekaragaman dianalisis secara deskriptif dalam bentuk gambar dan tabel. Mikroalga yang didapatkan dikelompokan berdasarkan hirarki taksonomi.

\section{Analisis Keanekaragaman}

Parameter uji dalam penelitian ini, meliputi indeks keanekaragaman ShannonWiener ( $\left.\mathrm{H}^{\prime}\right)$, indeks kemerataan (J'), indeks dominansi (D), indeks kekayaan (S) dan kelimpahan spesies mikroalga yang ditentukan sebagai berikut:

\section{a. Indeks Keanekaragaman Shannon-Wiener (H')}

Keanekaragaman mikroalga ditentukan dengan formula berikut :

$$
\mathrm{H}^{\prime}=-\Sigma(\mathrm{Pi}) \times(\ln \mathrm{Pi})
$$

Kriteria nilai indeks keanekaragaman Shannon - Wiener (H') adalah sebagai berikut:

$$
\begin{array}{ll}
H^{\prime}<1 & : \text { keanekaragaman rendah } \\
1<H^{\prime} \leq 3 & : \text { keanekaragaman sedang } \\
H^{\prime}>3 & : \text { keanekaragaman tinggi }
\end{array}
$$

\section{b. Indeks Kemerataan (J')}

Kemerataan spesies mikroalga ditentukan dengan formula berikut ini.

$$
\mathrm{J}^{\prime}=\mathrm{H}^{\prime} / \ln \mathrm{S}
$$

$$
\begin{aligned}
\text { Keterangan }: J^{\prime} & =\text { indeks kemerataan spesies } \\
\mathrm{H}^{\prime} & =\text { indeks keragaman Shannon-Wiener }\left(\mathrm{H}^{\prime}\right)
\end{aligned}
$$




$$
\mathrm{S}=\text { kekayaan spesies }
$$

\section{c. Indeks Dominansi (D)}

Dominansi mikroalga ditentukan dengan formula berikut ini.

$$
\mathrm{D}=\square \mathrm{Pi}^{2}
$$

\section{d. Indeks Kelimpahan relatif (\%)}

Kelimpahan spesies dihitung dengan menjumlahkan individu dalam spesies dari mikroalga. Berikut ini formula yang digunakan untuk menentukan kelimpahan spesies.

$$
\mathrm{KR}=-
$$

Keterangan : $\quad \mathrm{KR}=$ Kelimpahan relative

$$
\text { ni }=\text { individu spesies ke-i }
$$

$\mathrm{N}$ = Jumlah individu seluruh spesies

\section{HASIL DAN PEMBAHASAN}

\begin{tabular}{|c|c|c|c|c|c|c|}
\hline \multirow[t]{2}{*}{ No } & \multirow[t]{2}{*}{ Divisi } & \multirow[t]{2}{*}{ Ordo } & \multirow[t]{2}{*}{ Spesies } & \multicolumn{3}{|c|}{ Stasiun } \\
\hline & & & & 1 & 2 & $\mathbf{3}$ \\
\hline \multirow[t]{11}{*}{1} & Chlorophyta & Oedogoniales & Oedogonium sp. & 13 & 6 & 2 \\
\hline & & & Ankistrodesmus falcatus & 4 & 2 & 1 \\
\hline & & Sphaeroporoplaes & Quadrigula sp. & 3 & 5 & 2 \\
\hline & & & Kircnella lunaris & 12 & - & 2 \\
\hline & & & Coenocytis plantonema & - & 5 & - \\
\hline & & Zygnematales & Spirogyra sp. & 20 & 14 & 10 \\
\hline & & Desmidiales & Plourotaenium sp. & 5 & - & 1 \\
\hline & & & Closterium gracile & - & 4 & 2 \\
\hline & & & Ulotrix sp & 5 & 1 & 2 \\
\hline & & Ulotricales & & & & \\
\hline & & & Binuclearia tatrana & 2 & - & - \\
\hline \multirow[t]{6}{*}{2} & Bacillariophyta & Mastogliales & Achnantes sp. & 2 & 1 & - \\
\hline & & Cymbellales & Gomphonema olivaceum & 1 & 3 & 3 \\
\hline & & Centrales & Melosira varians & 1 & - & 4 \\
\hline & & Bacillariales & Bacilaria paxilifera & 1 & 4 & - \\
\hline & & & Fragilaria capunica & 5 & 1 & 6 \\
\hline & & Gonyaulacales & Ceratium hirudinella & 4 & 2 & 12 \\
\hline 3 & Pyrrhophyta & Peridinales & Peridinium umbonatum & 5 & 1 & 4 \\
\hline \multirow[t]{5}{*}{4} & Euglenophyta & Euglenales & Protoperidinium claudians & 4 & 21 & 8 \\
\hline & & & Phacus longicuda & 1 & - & - \\
\hline & & & Phacus chloroplates & 2 & 3 & - \\
\hline & & & Euglena sp. & 1 & 5 & - \\
\hline & & & Trachelomonas horrid & 7 & - & 4 \\
\hline
\end{tabular}

\section{Hasil Penelitian}

Tabel 1. Keanekaragaman mikroalga (jumlah individu/spesies) yang ditemukan di situ Cibanten 


\begin{tabular}{ccccccc}
\hline 5 & Rhodophyta & Batacospermales & Lemanea anulata & 1 & - & - \\
6 & Cyanophyta & Oscillatoriales & Oscillatoria tenuis & 3 & 1 & 11 \\
& Nostocales & Tolypothrix distorta & 2 & 1 & 5 \\
& Synechococales & Pseudanabaena sp. & - & 4 & 2 \\
& Jumlah & & 10 & & \\
& & & 4 & 64 & 81 \\
\hline
\end{tabular}

Tabel 2. Indeks keragaman shanon wiener

\begin{tabular}{cccc}
\hline Stasiun & Lokasi & $\begin{array}{c}\text { Indeks } \\
\text { Keanekaragaman } \\
\text { Shanon-Wiener (H') }\end{array}$ & Kategori \\
\hline 1 & Dekat bendungan & 3,110 & Tinggi \\
2 & Di bawah pohon & 2,367 & Sedang \\
3 & Terpapar sinar matahari & 2,630 & Sedang \\
\hline
\end{tabular}

Tabel 3. Indeks kemerataan Situ Cibanten

\begin{tabular}{ccc}
\hline Stasiun & Lokasi & Indeks Kemerataan (J') \\
\hline 1 & Dekat bendungan & 0,978 \\
2 & Dibawah pohon & 0,803 \\
3 & Terpapar sinar matahari & 0,909 \\
\hline
\end{tabular}

Tabel 4. Indeks Dominansi pada Situ Cibanten

\begin{tabular}{lcccc}
\hline \multirow{1}{*}{ Spesies } & \multicolumn{4}{c}{ Indeks Dominansi Pada Stasiun } \\
\cline { 2 - 5 } & $\mathbf{1}$ & $\mathbf{2}$ & $\mathbf{3}$ & Total \\
\hline Oedogonium sp & 0,015625 & 0,008789 & 0,00061 & 0,025024 \\
Ankistrodesmus & 0,001479 & 0,000977 & 0,000152 & 0,002608 \\
falcatus & & & & \\
Quadrigula sp & 0,000832 & 0,006104 & 0,00061 & 0,007546 \\
kirchnella lunaris & 0,013314 & 0 & 0,00061 & 0,013924 \\
Coenocytis planktonema & 0 & 0,006104 & 0 & 0,006104 \\
Spyrogira sp & 0,036982 & 0,047852 & 0,015242 & 0,100076 \\
Plourotenium sp & 0,002311 & 0 & 0,000152 & 0,002463 \\
Closterium gracile & 0 & 0,003906 & 0,00061 & 0,004516 \\
Ulotrix sp & 0,002311 & 0,000244 & 0,00061 & 0,003165 \\
Binuclearia tatrana & 0,00037 & 0,003906 & 0 & 0,004276 \\
Achnantes sp & 0,00037 & 0,000244 & 0 & 0,000614 \\
Gomphonema olivaceum & 0,000092 & 0,002197 & 0,001372 & 0,003661 \\
Melosira varians & 0,000092 & 0 & 0,002439 & 0,002531 \\
Bacillaria paxillifera & 0,000092 & 0,003906 & 0 & 0,003998 \\
Fragilaria capunica & 0,002311 & 0,000244 & 0,005487 & 0,008042 \\
Ceratium hirudinella & 0,001479 & 0,000977 & 0,021948 & 0,024404 \\
Peridinium umbonatum & 0,002311 & 0,000244 & 0,002439 & 0,004994 \\
Protoperidinium claudicans & 0,001479 & 0,000244 & 0,009755 & 0,011478 \\
Phacus longicauda & 0,000079 & 0 & 0 & 0,000079 \\
Phacus chloroplates & 0,00037 & 0,002197 & 0 & 0,002567 \\
Euglena sp & 0,000092 & 0,006104 & 0 & 0,006196 \\
Trachelomonas horrid & 0,00453 & 0 & 0,002439 & 0,006969 \\
Lemanea anmunlata & 0,000092 & 0 & 0 & 0,000092 \\
Oschilatoria tenuis & 0,000832 & 0,000244 & 0,018442 & 0,019518 \\
Tolipothrix distorta & 0,00037 & 0,000244 & 0,00381 & 0,004424 \\
Pseudanabaena sp & 0 & 0,003906 & 0,00061 & 0,004516 \\
\hline & & & & \\
\hline
\end{tabular}


Tabel 5. Indeks Kelimpahan Relatif Situ Cibanten

\begin{tabular}{ccc}
\hline Ordo & Spesies & Kelimpahan Relatif (\%) \\
\hline Oedogoniales & Oedogoniumsp & 8,43 \\
Saperophorales & Ankistrodesmus falcatus & 2,81 \\
& Quadrigulasp & 4,02 \\
Zygnematales & Kirchnella lunaris & 5,62 \\
& Coenocytis planktonema & 2,01 \\
Desmidiales Ulotricales & Spyrogirasp & 17,7 \\
& Plouroteniumsp & 2,41 \\
& Closterium gracile & 2,41 \\
Mastogliales & Ulotrixsp & 3,21 \\
Cymbelalles & Binuclearia tatrana & 0,8 \\
Centrales & Achnantes sp & 1,2 \\
& Gomphonema oliyaceum & 2,81 \\
Bacillariales & Melosira varians & 2,01 \\
Goniacuales & bacillaria paxilifera & 2,01 \\
Peridinales & Fragilaria capunica & 4,82 \\
& Ceratium hirudinella & 7,23 \\
Euglenales & Peridinium umbonatum & 4,02 \\
& Protoperidinium claudicans & 5,22 \\
Tocotal & Phacus longicauda & 0,4 \\
Synechocales & Phacus chloroplates & 2,01 \\
Oschilatoriales & Euglenasp & 2,41 \\
& Trachelomonas horrid & 4,42
\end{tabular}

Tabel 6. Parameter lingkungan situ Cibanten

\begin{tabular}{ccccc}
\hline No & Parameter Lingkungan & \multicolumn{3}{c}{ Stasiun } \\
\cline { 3 - 5 } & & I & II & III \\
\hline 1 & $\mathrm{pH}$ & 4,49 & 6,0 & 6,5 \\
2 & Suhu & $26^{\mathrm{O}} \mathrm{C}$ & $23^{\mathrm{O}} \mathrm{C}$ & $26^{\mathrm{o}} \mathrm{C}$ \\
3 & Kecerahan air & $215 \mathrm{~cm}$ & $145 \mathrm{~cm}$ & $200 \mathrm{~cm}$ \\
4 & DO & $3,9 \mathrm{mg} / \mathrm{L}$ & $3,7 \mathrm{mg} / \mathrm{L}$ & $4,1 \mathrm{mg} / \mathrm{L}$ \\
5 & COD & $81,4 \mathrm{mg} / \mathrm{L}$ & $79,1 \mathrm{mg} / \mathrm{L}$ & $81,3 \mathrm{mg} / \mathrm{L}$ \\
6 & BOD & $50,3 \mathrm{mg} / \mathrm{L}$ & $12,1 \mathrm{mg} / \mathrm{L}$ & $58,4 \mathrm{mg} / \mathrm{L}$ \\
\hline
\end{tabular}

\section{Pembahasan}

Berdasarkan hasil penelitian di situ Cibanten Kecamatan Ciomas Kabupaten serang mikroalga yang ditemukan terdiri dari 6 devisi, 16 ordo dan 26 spesies dengan jumlah total 249 individu.

\section{Divisi Chlorophyta}

Divisi Chlorophyta merupakan jenis mikroalga yang paling banyak ditemukan di Situ Cibanten dengan 5 ordo, yaitu Oedogoniales, Sphaeporales, Zygnematales, Desmidiales, dan Ulotrichales. 10 spesies yaitu Oedogonium sp, Ankisrodesmus 
falcatus, Quadrigula sp, Kirchnella lunaris, Coenocytis plantonema, Spirogyra sp, Plourotenium sp, Closterium gracile, Ulotrix sp, dan Binuclearia tatrana. Divisi Chlorophyta merupakan spesies yang paling banyak ditemukan di Situ Cibanten dibanding Divisi lainya, karena Chlorophyta memiliki range habitat yang luas mulai dari kolam, danau, bahkan laut. Berdasarkan pendapat Garno (2008) menyatakan bahwa komunitas mikroalga Divisi Chlorophyta kebanyakan hidup di perairan tawar.

\section{Divisi Bacillariophyta}

Divisi Bacillariophyta pada urutan kedua dengan ditemukannya 4 Ordo yaitu Mastogliales, Cymbrllales, Centrales dan Bcillariales, 5 spesies yaitu Achnantes sp, Gomphonema olivaceum, Melosira Varians, Bacillaria paxilifera, dan Fragilaria capunica.Bacillariophyta juga diketahui sebagai mikroalga yang merupakan bioindicator lingkungan untuk mengetahui tingkat pencemaran suatu perairan (Winahyu, dkk, 2013).

Divisi Bacillariophyta memiliki kemampuan beradaptasi terhadap arus yang kuat sampai arus lambat karena mempunyai alat penempel pada substrat berupa tangkai yang bergelatin (Andriansyah, dkk, 2014). Saat penelitian berlangsung lokasi penelitian tidak memiliki arus yang deras seperti sungai, mikroalga yang ditemukan diduga menempel pada tumbuhan yang terdapat di lokasi. Hal yang sama juga dinyatakan oleh Basmi (1999), bahwa ebagian besar anggota kelas Bacillariophyta mempunyai sitoplasma yang mengandung mukopolisakarida yang mampu mengeluarkan cairan perekat yang bisa menempel pada substrat.

\section{Divisi Euglenophyta}

Divisi Euglenophyta ditemukan 1 ordo yaitu Euglenales dan 4 spesies yaitu Phacus longicauda, Phacus chloroplates, Euglena sp, dan Thrachelomonas horrida. Euglenophyta di Situ Cibanten tidak banyak ditemukan seperti Divisi Chlorophyta dan Bacillariophyta karena biasanya Divisi Euglenophyta banyak ditemukan dan melimpah, sesekali mewarnai air kolam berwarna hijau tua, atau membentuk filamen berwarna hijau dipermukaan. Biasanya Euglena ditemukan berenang bebas diberbagai habitat, dapat ditemukan di setiap jenis perairan tawar maupun payau. Euglenophyta dapat berkembang biak dengan baik di lingkungan tercemar atau diperkaya banyak limbah organik (Vureen, et.al, 2006). 


\section{Divisi Pyrrophyta}

Divisi Pyrrophyta ditemukan 2 ordo, yaitu Peridinales dan Gonyaulacales dan 3 spesies yaitu Peridinium umbonatum, Protoperidinium claudicans, dan Ceratium hirudinella. Divisi Pyrrophyta atau biasa dikenal dengan dinoflagellata. Dinofalgellata air tawar umumnya tidak bersifat racun dan tidak berbahaya seperti Dinoflagellata air laut yang bersifat toksik dan memiliki efek negative pada sistem perairan. Namun, pada beberapa penelitian dilaporkan bahwa ada bebarapa organisme yang bersifat toksik bagi organisme lainnya terutama alga Peridinium.

Pyrrophyta dicirikan oleh sel-sel yang diperkuat oleh lempengan selulosa. Dua flagella yang dilekukan tegak lurus membuat Pyrrophyta bergerak memutar di dalam air (Campbell, 2003). Jenis fitoplankton bersel tunggal yang mampu berenang.

\section{Divisi Cyanophyta}

Divisi Cyanophyta ditemukan 3 ordo yaitu Oscillatoriales, Nostocales, dan Synecocales dan 3 spesies yaitu Oscillatoria tenuis, Tolypotrix distorta, dan Pseudonabaena sp.Berdasarkan Fukuyo (2000) ada beberapa fitoplankton yang dapat menjadi indikator perairan tercemar salah satunya Oscillatoria, hal ini dikarenakan Oscillatoria memiliki reproduksi aseksual berupa spora sehingga sifatnya yang memiliki toleransi tinggi terhadap kondisi perairan yang tercemar (Handayani 2009).

\section{Divisi Rhodophyta}

Divisi Rhodophyta ditemukan 1 ordo yaitu batracospermales dan 1 spesies yaitu Lemanea anulata. Jumlah divisi Rhodophyta yang ditemukan lebih sedikit disbanding yang lainnya dikarenakan biasanya mikroalga jenis Rhodophyta biasanya ditemukan di perairan lautan.

Berdasarkan hasil perhitungan diperoleh indeks keanekaragaman Shannon-Wiener (H') mikroalga di Situ Cibanten bervariasi.Indeks keanekaragaman yang paling tinggi terdapat pada stasiun 1 sebesar 3.110 (kategori tinggi), sedangkan indeks keanekaragaman terendah terdapat pada stasiun 2 sebesar 2.367 (kategori sedang). Indeks keanekaragaman di Situ Cibanten termasuk kedalam kategori sedang hingga tinggi dengan nilai $1<\mathrm{H}^{\prime}>3$.

Indeks keanekaragaman tertinggi terjadi pada stasiun 1 merupakan bagian tepi danau yang dengan area bendungan dan mendapatkan cahaya matahari, sehingga dapat meningkatkan produktivitas primer perairan. Cahaya merupakan faktor penting 
karena berdampak langsung terhadap distribusi dan jumlah organisme khususnya fitoplankton dalam badan air (Anggoro et al., 2013). Indeks keragaman pada situ Cibanten tergolong indeks keragaman kategori sedang.

Faktor lingkungan lain yang mendukung yaitu dikarenakan suhu yang terdapat pada staiun 1 sebesar $26^{\circ} \mathrm{C}$, stasiun dua $23^{\circ} \mathrm{C}$, dan staiun tiga $26^{\circ} \mathrm{C}$. Menurut Sari dkk (2013) bahwa mikroalga dapat tumbuh pada kisaran suhu optimum $22-30^{\circ} \mathrm{C}$. Derajat keasaman $(\mathrm{pH})$ dari suatu lingkungan perairan sering kali dipakai untuk menentukan baik buruknya suatu lingkungan hidup walaupun suatu perairan masih dipengaruhi oleh berbagai faktor (Erdiana, 2010). pH yang didapat di Situ Cibanten saat penelitian pada stasiun satu yaitu 4,87, stasiun dua 6,0 dan stasiun tiga yaitu 6,5. Menurut Kawaroe (2012) derajatkeasaman optimum untuk sebagian besar alga berkisar antara 6,5-9,5. Sedangkan menurut Pelczar (2010) mengatakan bahwa keasaman optimum pada alga yaitu 4-11.

Kecerahan air yang didapat di Situ Cibanten saat penelitian pada stasiun satu yaitu $215 \mathrm{Cm}$, stasiun dua $145 \mathrm{Cm}$, dan stasiun tiga yaitu $200 \mathrm{Cm}$. Hal ini menandakan bahwa kecarahan air di Situ Cibanten merupakan perairan yang sedikit keruh. Kecerahan atau cahaya merupakan salah satu faktor penting bagi pertumbuhan mikroalga yakni berguna untuk melakukan proses fotosintesis (Romomoharto \& Juwana, 2009).

DO yang didapat di Situ Cibanten saat penelitian pada stasiun satu yaitu 3,9 $\mathrm{mg} / \mathrm{L}$, stasiun dua 3,7 mg/L, dan stasiun tiga yaitu 4,1 mg/L.Nilai kadar DO di Situ Cibanten tergolong rendah karena tidak sesuai dengan kadar yang telah ditetapkan yaitu berkisar antara 6-8 mg/L. rendahnya kadar DO karena Situ Cibanten dimanfaatkan oleh masyarakat untuk kegiatan mandi dan mencuci (Saifullah, 2015).DO berpengaruh terhadap kualitas perairan sungai seperti pendapat Barus (dalam Tambun, 2011) menegaskan bahwa nilai oksigen terlarut di oksigen sebaiknya berkisar antara 6-8 mg/l, makin rendah nilai DO (Dissolved Oxygen) maka makin tinggi tingkat pencemaran ekosistem tersebut.

COD (Chemical Oxygen Demand) adalah jumlah oksigen yang diperlukan untuk mengurai seluruh bahan organik yang terkandung dalam air (Boyd, 1990). Hasil penelitian di Situ Cibanten COD pada stasiun satu yaitu 81,4 mg/L, stasiun dua 79,1 mg/L, dan stasiun tiga yaitu 81,3 mg/L.hasil kadar COD di Situ Cibanten 
dikatogorikan tinggi karena mendekati batas maksimun yaitu 100 mg/L. Hal ini karena bahan organik yang ada sengaja diurai secara kimia dengan menggunakan oksidator kuat kalium bikromat pada kondisi asam dan panas dengan katalisator perak sulfat (Boyd, 1990; Metcalf \& Eddy, 1991), sehingga segala macam bahan organik, baik yang mudah terurai maupun bahan organik kompleks dan sulit urai, akan teroksidasi. Dengan demikian, selisih nilai antara COD dan BOD memberikan gambaran besarnya bahan organik yang sulit urai yang ada di perairan.

BOD yang didapat di Situ Cibanten saat penelitian pada stasiun satu yaitu 50,3 $\mathrm{mg} / \mathrm{L}$, stasiun dua 12,1 $\mathrm{mg} / \mathrm{L}$, dan stasiun tiga yaitu $58,4 \mathrm{mg} / \mathrm{L}$. BOD atau Biochemical Oxygen Demand adalah suatu karakteristik yang menunjukkan jumlah oksigen terlarut yang diperlukan oleh mikroorganisme (biasanya bakteri) untuk mengurai atau mendekomposisi bahan organik dalam kondisi aerobik (Atima, 2015).

Indeks kemerataan pada stasiun 1 sebesar 0.978 , stasiun 2 sebasar 0.803 , pada stasiun 3 sekitar 0.909. Indeks kemerataan di Situ Cibanten berkisar antara 0,8030,978. Indeks kemerataan pada stasiun 1 sebesar 0.978 , stasiun 2 sebasar 0.803 , pada stasiun 3 sebesar 0.909. Indeks kemerataan tertinggi terdapat pada stasiun 1 yaitu sebesar 0,978 sedangkan indeks kemerataan terendah terdapat padat stsiun 2 sebesar 0,803 . Walaupun indeks kemerataan pada stasiun 2 memiki nilai indeks lebih rendah dibandikan yang lainnya tetapi memiki nilai yang besar yaitu 0,803. Berdasarkan pada nilai indeks kemerataan bahwa situ cibanten memiliki nilai indeks kemerataan yang tinggi karena memiliki spesies yang beragam dan tidak adanya salah satu spesies yang mendominasi.

Basmi (1999) menyebutkan bahwa kemerataaan individu suatu biota yaitu 0-0,5 (kemerataan antar individu rendah) artinya kekayaan individu yang dimiliki masingmasing spesies sangat jauh berbeda atau tidak seragam, dan kemerataan individu biota $0,6-1$ (Kemerataan individu relatif seragam atau jumlah individu masing-masing spesies relatif sama). Jika merujuk pada pendapat ini kemerataan mikroalga di Situ Cibanten memiliki kerapatan jenis yang tinggi, karena jenis individu relatif seragam atau jumlah individu masing-masing relative sama.

Indeks dominansi (D) menggambarkan ada atau tidaknya biota perairan yang mendominasi (Odum, 1996). Hasil perhitungan menunjukan bahwa mikroalga yang terdapat di Situ Cibanten lebih banyak memiliki niai mendekati angka 0 dibanding 
angka 1. Jika indeks dominansi mendekati nilai 1 maka ada salah satu jenis yang mendominasi daripada jenis lain, hal ini disebabkan karena mikroalga mengalami tekanan ekologis berupa stres (Nugroho, 2006).

Indeks kelimpahan relatif (\%) yaitu proporsi masing masing spesies dari setiap jumlah individu yang dipresentasikan dalam suatu komunitas (Campbell, 2002).

Indeks kelimpahan relatif di Situ Cibanten mendapatkan hasil yang beragam. Indeks terbesar yaitu Spirogyra sp sebesar $17.7 \%$ sedangkan yang terkecil yaitu Lemanea annulata dan Phacus longicauda sebesar $0.14 \%$.

\section{KESIMPULAN}

1. Mikroalga yang ditemukan di Situ Cibanten terdiri dari 249 individu dari 26 spesies yaitu Oedogonium sp, Ankistrodesmus falcatus, Quadrigula sp, kirchnella lunaris, coenocytis planktonema, Spyrogira sp, Plourotenium sp, Closterium gracile, Ulotrix sp, Binuclearia tatrana, Achnantes sp, Gomphonema olivaceum, Melosira Varians, Bacilaria paxilifera, Fragilaria capunica, Ceratium hirudinella, Peridinium umbonatum, Protoperidium claudicans, Phacus longicauda, Phacus chloroplates, Euglena sp, Thracelomonas horrida, Lemanea annulata, Oscilatoria tenuis, Tolypotrix distorta, dan Pseudanabaena.

2. Indeks Keanekaragaman yang tertinggi terdapat pada stasiun 1 dengan 3.110 dan terendah terdapat pada stasiun 2 dengan 2.360. Indeks kemerataan tertinggi terdapat pada stasiun 1 dengan nilai 0.978 sedangkan indeks kemerataan terendah terdapat pada stasiun 2 dengan nilai 0.803 . Indeks dominansi pada setiap spesies mendapatkan nilai hampir mendekati nol sehingga indeks dominansi rendah. Serta Indeks kelimpahan relatif yang tertinggi terdapat pada spesies Spirogyra dengan nilai $17.7 \%$ dan terendah terdapat pada spesies Phacus longicaida dan Lemanea annulata dengan nilai $0.4 \%$. Menurut hasil dari indeks keanekaragaman Situ Cibanten termasuk dalam kategori Tercemar sedang.

\section{DAFTAR PUSTAKA}

Andriansyah., Tri.Setyawati, R., \& Lovadi, I. (2014). Kualitas Perairan Kanal Sungai Jawi Dan Sungai Raya Dalam Kota Pontianak Ditinjau Dari Struktur Komunitas Mikroalga Perifitik. Jurnal Protobiont. 3 (1). 
Anggoro, S.,Soedarsono, P., dan Suprobo, H.D. (2013). Penilaian Pencemaran Perairan di Polder Tawang Semarang ditinjau dari Aspek Saprobitas. Journal of Management of Aquatic Resources 2 (3).

Atima, W. (2015). BOD dan COD Sebagai Parameter Pencemaran Air dan Baku Mutu Air Limbah. Jurnal Biology and Education BiologiSel Vol. 4 No. 1.

Erdina, L., Aulia, A., Hardiansyah. (2010). Keanekaragaman dan Kemelimpahan Alga Mikrokopis Pada Daerah Persawahan Di Desa Sungai Lumbah Kecamatan Alalak Kabupaten Barito Kuala. Barito Kuala. J.Wahana-Bio. 1(3)

Handayani ST, Suharto B, Marsoedi. (2009). Penentuan Status Kualitas Perairan Sungai Brantas Dengan Biomonitoring Makrozoobentos: Tinjauan Dari Pencemaran Bahan Organik. Biosain, Vol.1 No. 1.

Harmoko., Krisnawati, Y. (2018). Keanekaragaman Mikroalga Divisi Cyanobacteria di Danau Aur Kabupaten Musi Rawas. Jurnal Biodjati 3 (1).

Pambudi,A., Priambodo, W. P.,Noriko, N., dan Basma. (2016). Keanekaragaman Fitoplankton Sungai Ciliwung Pasca Kegiatan Bersih Ciliwung. Jurnal Al-Azhar Indonesia Seri Sains dan Teknologi, Vol. 3, No. 4.

Saefullah, Hermawan D, dan Purnomo BH. (2015). Kualitas Air Situ Cibanten Berdasarkan Indeks Keanekaragaman Shannon- Weaver. Jurnal perikanan dan kelautan vol 5 no 1 : 1-4.

Soetanto, A., Purwasih. (2012). Analisis Kualitas Perairan Sungai Raman Desa Pujodadi Trimurjo Sebagai Sumber Belajar Biologi Sma Pada Materi Ekosistem. Bioedukasi, vol 2 No 2: 1-9.

Susilo H, Hakim M, Setiawan U. (2021). Biodivesrsitas Laba-laba Arachina (Araneae) Di Kawasan Ekosistem Desa Wisata Banyubiru Kecamatan Labuan Kabupaten Pandeglang. Jurnal Lingkungan dan Sipil, 4(1) 56-69.

Tambun, R. (2011). Konsep Pengelolaan Kualitas Air Sungai Berdasarkan Indikator Biologis Makroinvertebrata Air. Medan: Pascasarjana UNSU.

Tjitroesoepomo, G. (2014). Taksonomi Tumbuhan. Jogjakarta : Gadjah Mada University Press

Winahyu, D.A, A.Yulistia, L.R. Elly, M. Jani dan S.Andi. (2013). Studi Pendahuluan Mengenai Keanekaragaman Mikroalga di PusatKonservasi Gajah, Taman Nasional Way Kambas. Prosiding Semirata FMIPA Universitas Lampung. 